\title{
Efek Antidiabetes Kombinasi Ekstrak Bawang Putih (Allium sativum Linn.) dan Rimpang Kunyit (Curcumma domestica Val.) dengan Pembanding Glibenklamid pada Penderita Diabetes Melitus Tipe 2
}

\author{
Ame Suciati Setiawan, ${ }^{1}$ Elin Yulinah, ${ }^{2}$ I Ketut Adnyana, ${ }^{2}$ Hikmat Permana ${ }^{3}$, Primal Sudjana ${ }^{3}$ \\ ${ }^{1}$ Departemen Oral Biologi-Farmakologi Fakultas Kedokteran Gigi Universitas Padjadjaran; \\ ${ }^{2}$ Program Studi Farmakologi-Toksikologi Sekolah Farmasi Institut Teknologi Bandung; \\ ${ }^{3}$ Departemen Ilmu Penyakit Dalam Fakultas Kedokteran Universitas Padjadjaran- \\ Rumah Sakit Dr. Hasan Sadikin Bandung
}

\begin{abstract}
Abstrak
Kombinasi ekstrak bulbus bawang putih (Allium sativum Linn.) dan rimpang kunyit (Curcumma domestica Val.) dapat digunakan sebagai obat antidiabetes oral pada penderita diabetes melitus (DM) tipe 2, dan secara klinis telah terbukti dapat menurunkan kadar glukosa darah dengan dosis 2,4 g/hari. Penelitian klinis dilakukan untuk melihat efek antidiabetes kombinasi ekstrak dibandingkan dengan antidiabetik oral, glibenklamid. Subjek adalah usia $>35$ tahun dengan DM tipe 2 yang berobat ke poliklinik Penyakit Dalam dan Endokrin Rumah Sakit Hasan Sadikin Bandung periode November 2007-Agustus 2008 dan telah mendapat terapi gizi medis selama 2 minggu. Penelitian dilakukan secara paralel, acak, dan tersamar ganda. Penggunaan kombinasi ekstrak menunjukkan penurunan kadar glukosa darah puasa rata-rata 9,25 mg/dL, glukosa darah 2 jam postprandial (PP) 22,25 mg/dL, HbA1c 1,30\%, serta insulin 12,57 mg/dL bila dibandingkan dengan baseline glibenklamid rata-rata kadar glukosa darah puasa $72,37 \mathrm{mg} / \mathrm{dL}$, glukosa darah 2 jam PP $114,25 \mathrm{mg} / \mathrm{dL}$, dan HbA1c 4,12\%, tetapi meningkatkan insulin 3,34 mg/ dL. Kombinasi ekstrak tidak mempengaruhi fungsi hati, ginjal, dan profil hematologi. Kesimpulannya kombinasi ekstrak memiliki efek antidiabetes tetapi efek yang ditimbulkan tidak sebaik glibenklamid.
\end{abstract}

[MKB. 2011;43(1):26-34].

Kata kunci: Bawang putih, kunyit, diabetes melitus tipe 2, glibenklamid, glukosa darah

\section{Antidiabetic Effect of Garlic Extract (Allium sativum Linn.) and Curcumin Extract (Curcumma domestica Val.) Combination Compared to Glibenclamide in Type 2 Diabetes Mellitus}

\begin{abstract}
The combination of garlic (Allium sativum Linn.) and curcumin extract (Curcumma domestica Val.) can be used as an oral antidiabetic in type 2 diabetes mellitus (DM) patients. The clinical trial has shown that the extract can decrease blood glucose at a dose of $2.4 \mathrm{~g} /$ day. This clinical trial was conducted to explore the antidiabetic effect of garlic and curcumin extract combination compared to oral antidiabetics, glibenclamide. The subjects were $>35$ years old patients with type 2 DM who visited the internal and endocrine clinic of Dr. Hasan Sadikin Hospital Bandung and has been treated with medical nutrition therapy for 2 weeks during the period of November 2007December 2008. This study was a parallel, randomized and double blind study. The garlic and curcumin extract combination decreased the mean value of fasting blood glucose $9.25 \mathrm{mg} / \mathrm{dL}, 2 \mathrm{~h}$ PP blood glucose $22.25 \mathrm{mg} / \mathrm{dL}$, HbA1c 1,30\% and insulin $12.57 \mathrm{mg} / \mathrm{dL}$ compared to baseline whereas glibenclamide decreased the mean value of fasting blood glucose to $72.37 \mathrm{mg} / \mathrm{dL}, 2 \mathrm{~h}$ PP $114,25 \mathrm{mg} / \mathrm{dL}, \mathrm{HbA} 1 \mathrm{c} 4.12 \%$ and increased the insulin to $3.34 \mathrm{mg} /$ $\mathrm{dL}$. In conclusion, the extract combination has antidiabetic effect even though it is lower than the glibenclamide. [MKB. 2011;43(1):26-34].
\end{abstract}

Key words: Blood glucose, curcumin, garlic, glibenclamide, type 2 diabetes mellitus

Korespondensi: Ame Suciati Setiawan, drg., M.Si, Bagian Oral Biologi-Farmakologi Fakultas Kedokteran Gigi Universitas Padjadjaran, jalan sekeloa 1 Bandung, mobile 08122383860, e-mail amesuciati@gmail.com 


\section{Pendahuluan}

Diabetes melitus (DM) adalah menurunnya fungsi pankreas untuk memproduksi insulin atau reseptor insulin tidak peka sehingga terjadi gangguan metabolisme; glukosa tidak diubah menjadi glikogen dan glukosa tidak dapat masuk ke dalam sel sehingga glukosa darah meningkat. ${ }^{1}$ Keluhan yang dapat ditemukan pada penderita diabetes melitus berupa keluhan klasik, yaitu poliuria, polidipsia, polifagia, dan penurunan berat badan (BB) yang cepat dan tidak diketahui penyebabnya. Keluhan lain dapat berupa lemah badan, parestesi, gatal, mata kabur, disfungsi ereksi pada pria, dan pruritus vulva pada wanita. ${ }^{2}$

Kriteria diagnosis DM berdasarkan WHO $2006,{ }^{3}$ yaitu bila kadar glukosa plasma puasa $\geq 126$ $\mathrm{mg} / \mathrm{dL}$ atau 2 jam postprandial (PP) $\geq 200 \mathrm{mg} /$ dL atau bila terjadi kedua-duanya. Perkumpulan Endokrinologi Indonesia (PERKENI) 2006 menyatakan kriteria diagnosis DM bila ditemukan keluhan klasik DM seperti poliuria, polidipsia dan polifagia, maka glukosa darah sewaktu $\geq 200$ $\mathrm{mg} / \mathrm{dL}$ sudah dapat digunakan untuk menentukan diagnosis diabetes melitus.

Diabetes melitus tipe 2 atau non insulin dependent diabetes mellitus (NIDDM) adalah kelainan yang ditandai resistensi dan defisiensi insulin atau terjadinya kegagalan sekresi insulin dan peningkatan kadar glukosa darah. ${ }^{1}$ WHO memprediksi kenaikan jumlah penderita dari 8,4 juta pada tahun 2002 menjadi sekitar 21,3 juta pada tahun $2030 .^{3}$

Terapi DM yang paling utama adalah terapi makanan dengan mengatur pola makan penderita bekerjasama dengan ahli gizi untuk menentukan makanan apa yang dapat dikonsumsi. Obatobatan dapat diberikan bila terapi makanan tidak berhasil. $^{2}$

Pada penderita DM tipe-2 yang mendapat antidiabetes oral, salah satu yang sering digunakan di Indonesia adalah golongan sulfonilurea. ${ }^{2}$ Secara umum obat ini merupakan antidiabetik oral yang baik untuk terapi DM tipe-2 atau NIDDM. Salah satu obat yang banyak digunakan di Indonesia adalah glibenklamid. ${ }^{2}$

Obat-obatan tradisional saat ini banyak dikembangkan sebagai antidiabetik, di antaranya bulbus bawang putih (Allium sativum Linn.) dan rimpang kunyit (Curcuma domestica Val.).

Unsur kimia utama dalam bawang putih adalah alliin yang merupakan cysteine sulfoxide dan peptida $\gamma$-glutamilcysteine. Bawang putih dalam bentuk serbuk berisi $1 \%$ alliin (S-allyl cysteine sulfoxide). Salah satu bentuk aktif bawang putih adalah allicin (diallyl tiosulfonate atau diallyl disulfide). Pada saat bawang putih dipotong enzim alinase akan diaktivasi dan alliin berubah menjadi allicin, selanjutnya allicin dimetabolisme menjadi vinyl-ditiines. ${ }^{4}$

Penelitian yang dilakukan pada tikus diabetes melitus yang diinduksi streptozotosin, pemberian bawang putih $500 \mathrm{mg} / \mathrm{kgBB}$ secara intraperitoneal selama 7 minggu menyebabkan penurunan kadar glukosa, kolesterol, dan trigliserida darah secara bermakna. ${ }^{5}$

Ekstrak bulbus bawang putih yang diberikan pada tikus yang diinduksi streptozotosin menurunkan hiperfagia dan polidipsia. ${ }^{6}$ Allicin yang diberikan secara oral pada tikus yang diinduksi aloksan menurunkan kadar glukosa dan meningkatkan aktivitas insulin.?

Kunyit (Curcumma domestica) merupakan tanaman yang digunakan untuk bumbu masakan, obat-obatan, dan bahan pewarna di India, Cina, dan Asia Tenggara. Curcumma mengandung protein $(6,3 \%)$, minyak $(13,1 \%)$, mineral $(3,5 \%)$, karbohidrat $(69,4 \%)$, dan lemak $(5,1 \%)$. Minyak esensial $(5,8 \%)$ yang didistilasi dari rimpangnya mengandung a-phellandrene $(1 \%)$, sabinene $(0,6 \%)$, cineol $(1 \%)$, borneol $(0,5 \%)$, zingiberene (25\%), dan sesquiterpines (53\%). Curcumin (diferuloylmethane) (3-4\%) menunjukkan warna kuning pada kunyit dan terdiri atas curcumin I (94\%), curcumin II (6\%), dan curcumin III $(0,3 \%)$. Demethoxy dan bisdemethoxy merupakan derivat yang dapat diisolasi dari curcumin.?

Curcumin sebagai bahan aktif kunyit memiliki aktivitas biologis yang luas, seperti antiinflamasi, antidiabetes, antikarsinogenik, antioksidan, antikoagulan, antibakteri, antihipertensi, dan antidislipidemia. ${ }^{7}$

Curcumin sebagai antidiabetes menurunkan kadar glukosa darah tikus yang diinduksi aloksan. Curcumin pada dosis rendah dapat mencegah terjadinya katarak yang disebabkan galaktosa dan menurunkan glikasi berat pada penderita diabetes melitus. Ekstrak kunyit juga dapat menekan peningkatan kadar glukosa darah pada Kk-Ay tikus dengan diabetes melitus tipe $2 .^{8}$

Berdasarkan hal di atas, kombinasi ekstrak bawang putih dan rimpang kunyit telah terbukti mempunyai efek antidiabetes secara in vivo.

Penelitian pada model hewan diabetes melitushiperkolesterolemia yang diinduksi aloksan, 100 $\mathrm{mg} / \mathrm{kg}$ bobot badan penggunaan kombinasi bulbus bawang putih (Allium sativum) dan rimpang kunyit (Curcuma domestica) menurunkan kadar glukosa dan kolesterol secara bermakna. ${ }^{9}$

Penelitian sebelumnya menunjukkan dosis kombinasi ekstrak bulbus bawang putih dan rimpang kunyit yang efektif untuk menurunkan kadar glukosa darah adalah 2,4 g/hari. ${ }^{10}$

Hasil uji toksisitas kronik dan subkronik pada hewan uji, kedua ekstrak tersebut tidak toksik sehingga aman untuk digunakan. ${ }^{11}$ 
Berdasarkan hasil uji klinis tersebut, maka dilakukan penelitian lanjutan untuk mengetahui efektivitas pemberian kombinasi ekstrak bulbus bawang putih dan rimpang kunyit dibandingkan dengan obat standar glibenklamid pada penderita DM tipe 2.

\section{Metode}

Sediaan obat uji yang digunakan adalah kapsul mengandung $200 \mathrm{mg}$ ekstrak bulbus bawang putih dan $200 \mathrm{mg}$ ekstrak rimpang kunyit dengan kandungan zat aktif alliin 6-7 mg per $200 \mathrm{mg}$ dan curcumin 37,5-42,5 mg per $200 \mathrm{mg}$. Selain itu obat pembanding yang digunakan adalah obat glibenklamid $5 \mathrm{mg}$.

Penelitian merupakan uji klinis dengan membandingkan efek kombinasi bulbus bawang putih dan rimpang kunyit dengan obat standar glibenklamid terhadap penurunan kadar glukosa darah. Parameter yang dilihat untuk mengetahui efek antidiabetes, yaitu dengan melihat kadar glukosa darah puasa, kadar glukosa darah 2 jam PP, HbAlc, dan insulin. Penelitian dilakukan dengan pengelompokan subjek secara random sederhana, prospektif, paralel, dan studi tersamar ganda. Uji statistik yang dilakukan pada penelitian ini adalah dengan uji t dengan dua sampel independen.

Penelitian uji klinik ini dilaksanakan dari bulan November 2007 sampai dengan Agustus 2008 ini telah mendapatkan persetujuan dari Komite Etik Rumah Sakit Hasan Sadikin Bandung. Jumlah subjek penelitian adalah 19 orang dengan kriteria inklusi penderita DM tipe 2 dengan kadar glukosa plasma sewaktu $\geq 200$ $\mathrm{mg} / \mathrm{dL}$ atau glukosa plasma puasa $\geq 126 \mathrm{mg} / \mathrm{dL}$ dengan atau tanpa disertai dislipidemia (kolesterol total $>200 \mathrm{mg} / \mathrm{dL}$ atau kolesterol LDL $>130 \mathrm{mg} /$ dL) yang belum pernah mendapatkan terapi obat hipoglikemia oral ataupun insulin sebelumnya dan telah mendapatkan terapi gizi medis selama 2 minggu, laki-laki atau wanita, usia lebih dari 35 tahun yang datang ke poliklinik Endokrin dan Penyakit Dalam Rumah Sakit Hasan Sadikin Bandung dan bersedia mengikuti penelitian dengan menandatangani surat persetujuan terapi (informed concent).

Penderita DM tipe 1 atau penderita yang telah mendapat terapi sebelumnya, penderita dengan gagal ginjal dan hati, penggunaan steroid atau pil kontrasepsi yang dapat mempengaruhi glukosa darah, penderita yang disertai komplikasi ketoasidosis dan ulkus atau gangren diabetikum serta wanita hamil dan menyusui tidak dapat diikutsertakan sebagai subjek penelitian.

Penderita yang memenuhi kriteria inklusi, dilakukan anamnesis dan pemeriksaan fisis berupa pengukuran berat badan, tinggi badan, tekanan darah, nadi dan respirasi, lalu penderita mendapat terapi gizi medis selama 2 minggu dan tidak mendapatkan terapi farmakologi.

Setelah 2 minggu terapi gizi medis atau pada minggu ke-2 dilakukan pemeriksaan fisis (tekanan darah, nadi, respirasi, berat badan) dan laboratorium. Pemeriksaan laboratorium yang dilakukan adalah hematologi ( $\mathrm{Hb}$, leukosit, hematokrit, trombosit), prothrombin time (PT), international normalize ratio (INR), activated partial thromboplastin time (APTT), fungsi hati (SGOT, SGPT), fungsi ginjal (ureum dan kreatinin), fungsi jantung ( $\mathrm{EKG})$, gula darah puasa (GDP), gula darah 2 jam postprandial (GD2PP), HbAlc, insulin, kolesterol total (KT), kolesterol LDL (low density lipoprotein), kolesterol HDL (high density lipoprotein), trigliserida, serta urin rutin $(\mathrm{pH}$, berat jenis, dan protein).

Bila hasil pemeriksaan sesuai dengan kriteria inklusi maka penderita menjadi subjek penelitian dan bila terdapat 1 atau lebih kriteria eksklusi maka penderita dikeluarkan dari subjek penelitian. Subjek yang masuk dalam kriteria inklusi dibagi menjadi 2 kelompok, yaitu kelompok I diberi obat uji dengan dosis 2,4 g setiap hari: kapsul $400 \mathrm{mg}$ mengandung $200 \mathrm{mg}$ bulbus bawang putih dan $200 \mathrm{mg}$ rimpang kunyit, aturan dosis 2x3 kapsul uji (pagi dan sore) setelah makan. Kelompok II diberi obat standar glibenklamid 5 mg dengan aturan dosis/hari adalah $2 \times 3$ kapsul, 1 kapsul berisi glibenklamid dan 2 kapsul bahan pembawa (pagi setelah makan) dan 3 kapsul bahan pembawa (sore setelah makan). Subjek penelitian mendapat terapi selama 3 bulan (14 minggu).

Pada minggu ke-4, -6, -10, dan ke-12 pemeriksaan laboratorium yang dilakukan adalah GDP, GD2PP, kolesterol total, LDL, HDL, trigliserida, dan urin rutin. Pada minggu ke-8 pemeriksaan laboratorium yang dilakukan adalah GDP, GD2PP, kolesterol total, HDL, LDL, trigliserida, urin rutin, serta fungsi hati dan ginjal. Pada minggu ke-14 dilakukan kembali pemeriksaan laboratorium lengkap.

\section{Hasil}

Jumlah subjek yang masuk dalam kriteria inklusi sebanyak 19 orang, subjek yang menyelesaikan terapi sesuai protokol selama 3 bulan sebanyak 8 orang mendapat terapi kombinasi bawang putihkunyit dan 8 orang mendapat terapi glibenklamid. Subjek yang tidak melanjutkan terapi 2 orang dari kelompok bawang putih-kunyit (1 orang tidak patuh karena menggunakan kortikosteroid dan 1 
orang lost of control) dan 1 orang dari kelompok glibenklamid lost of control.

Dari semua subjek penelitian, 11/16 subjek adalah wanita dan 5/11 laki-laki. Subjek memiliki usia rata-rata 58,10 tahun pada kelompok I (kelompok obat uji) dan 51,33 tahun pada kelompok II (kelompok obat standar) dan total usia rata-rata 55,79 tahun pada kedua kelompok.

Glukosa darah puasa merupakan parameter yang digunakan untuk mengetahui keadaan DM penderita. Pemeriksaan glukosa darah puasa dilakukan ketika penderita puasa sekurangkurangnya 8 jam. Penderita dengan glukosa darah puasa $\geq 126 \mathrm{mg} / \mathrm{dL}$ dinyatakan sebagai penderita diabetes melitus.

Hasil pemeriksaan glukosa darah puasa ratarata pada kedua kelompok mengalami penurunan $9,25 \mathrm{mg} / \mathrm{dL}$, dari $139,13 \mathrm{mg} / \mathrm{dL}$ menjadi $129,88 \mathrm{mg} / \mathrm{dL}$ pada kelompok I $(\mathrm{p}=0,194)$ dan pada kelompok II sebesar 72,37 mg/dL, dari
$246,63 \mathrm{mg} / \mathrm{dL}$ menjadi $174,25 \mathrm{mg} / \mathrm{dL} ; \mathrm{p}=0,068$ (Gambar 1). Hasil ini menunjukkan perbedaan antara penggunaan kombinasi bulbus bawang putih-rimpang kunyit dan glibenklamid dalam menurunkan kadar glukosa darah puasa.

Parameter lain adalah kadar glukosa darah 2 (dua) jam PP. Glukosa darah dua jam PP pada kelompok I menunjukkan penurunan rata-rata $22,25 \mathrm{mg} / \mathrm{dL}$ dibandingkan dengan baseline, secara statistik tidak bermakna $(p=0,394)$. Pada kelompok II penurunan kadar glukosa darah rata-rata dua jam PP sebesar 114,25 mg/dL bila dibandingkan dengan baseline, penurunannya bermakna secara statistik $(\mathrm{p}=0,021)$ seperti tampak pada Gambar 2. Untuk menurunkan kadar glukosa darah dua jam PP, terdapat perbedaan penggunaan kombinasi bulbus bawang putih dan rimpang kunyit dibandingkan dengan glibenklamid.

Gambar 3 menunjukkan efek penggunaan

Tabel 1 Data Baseline Subjek

\begin{tabular}{|c|c|c|c|}
\hline Pemeriksaan & $\begin{array}{c}\text { Kombinasi Ekstrak } \\
\text { Minggu ke-2 }(\mathrm{R} \pm \mathrm{SD})\end{array}$ & $\begin{array}{c}\text { Glibenklamid } \\
\text { Minggu ke-2 } \\
(\mathrm{R} \pm \mathrm{SD}) \\
\end{array}$ & $\mathbf{p}$ \\
\hline Usia (th) & $59,00 \pm 2,26$ & $53,00 \pm 8,12$ & 0,268 \\
\hline IMT $\left(\mathrm{kg} / \mathrm{m}^{2}\right)$ & $24,71 \pm 3,75$ & $25,03 \pm 5,62$ & 0,893 \\
\hline Sistolik (mg/dL) & $134,37 \pm 14,98$ & $55,62 \pm 11,15$ & 0,570 \\
\hline Diastolik (mg/dL) & $81,87 \pm 3,72$ & $82,50 \pm 4,62$ & 0,770 \\
\hline Hemoglobin (g/dL) & $13,73 \pm 1,55$ & $14,42 \pm 1,10$ & 0,325 \\
\hline Leukosit $\left(10^{3} \mathrm{~mm}^{3}\right)$ & $8,63 \pm 2,72$ & $84,87 \pm 19,92$ & 0,902 \\
\hline Hematokrit (\%) & $40,30 \pm 5,58$ & $41,12 \pm 2,95$ & 0,281 \\
\hline Trombosit $\left(10^{3} \mathrm{~mm}^{3}\right)$ & $282,75 \pm 91,54$ & $259,87 \pm 62,21$ & 0,568 \\
\hline PT (dtk) & $12,5 \pm 0,36$ & $12,47 \pm 0,50$ & 1,000 \\
\hline APTT (dtk) & $27,85 \pm 3,12$ & $29,10 \pm 3,03$ & 0,449 \\
\hline INR (dtk) & $0,93 \pm 0,03$ & $0,92 \pm 0,03$ & 0,005 \\
\hline SGOT (U/L) & $20,63 \pm 5,23$ & $19,75 \pm 8,44$ & 0,807 \\
\hline SGPT (U/L) & $18.00 \pm 5,32$ & $24,88 \pm 8,61$ & 0,075 \\
\hline Ureum (mg/dL) & $25,87 \pm 7,00$ & $27,12 \pm 5,46$ & 0,696 \\
\hline Kreatinin (md/dL) & $0,92 \pm 0,19$ & $0,69 \pm 0,14$ & 0,019 \\
\hline Gula darah puasa (mg/dL) & $139,13 \pm 35,54$ & $246,63 \pm 50,21$ & 0,000 \\
\hline Gula darah 2 jam PP (mg/dL) & $221,13 \pm 60,81$ & $374,50 \pm 90,52$ & 0,001 \\
\hline HbA1c (\%) & $8,80 \pm 2,00$ & $12,73 \pm 1,33$ & 0,000 \\
\hline Insulin (mg/dL) & $72,20 \pm 67,03$ & $52,24 \pm 53,09$ & 0,520 \\
\hline Kolesterol total $(\mathrm{mg} / \mathrm{dL})$ & $217,25 \pm 55,64$ & $232,13 \pm 21,86$ & 0,499 \\
\hline HDL (mg/dL) & $43,38 \pm 8,31$ & $42,38 \pm 6,30$ & 0,790 \\
\hline LDL (mg/dL) & $135,13 \pm 49,81$ & $148,00 \pm 18,56$ & 0,505 \\
\hline Trigliserida $(\mathrm{mg} / \mathrm{dL})$ & $145,38 \pm 56,76$ & $208,50 \pm 104,67$ & 0,156 \\
\hline
\end{tabular}




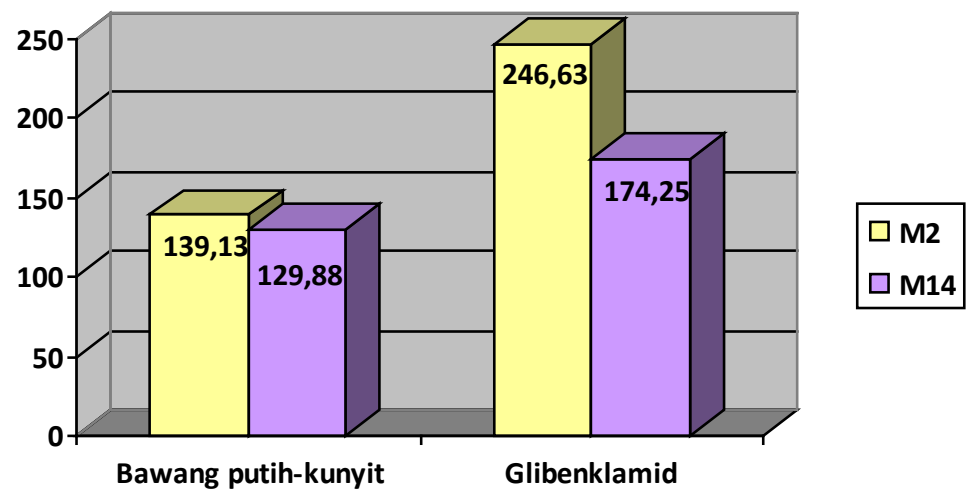

Gambar 1 Diagram Nilai Glukosa Darah Puasa Rata-rata pada Minggu ke-2 dan Minggu ke-14

kombinasi bawang putih dan kunyit (kelompok I) terhadap $\mathrm{HbAlc}$ terjadi penurunan rata-rata sebesar $1,30 \%$ dibandingkan dengan baseline, secara statistik tidak bermakna $(\mathrm{p}=0,064)$. Pada kelompok II terjadi penurunan HbA1c sebanyak $4,12 \%$ dibandingkan dengan baseline, secara statistik bermakna $(\mathrm{p}=0,00)$. Hasil analisis kedua kelompok menunjukkan tidak terdapat perbedaan penggunaan kombinasi bulbus bawang putih dan kunyit dengan glibenklamid.

Kadar insulin pada kelompok I menunjukkan penurunan kadar insulin rata-rata 12,57 , secara statistik tidak bermakna $(p=0,402)$, sedangkan pada kelompok II terjadi peningkatan kadar insulin rata-rata sebesar 3,34 dan tidak bermakna $(\mathrm{p}=0,663)$.

Parameter penunjang pada penelitian ini adalah indeks massa tubuh (IMT), tekanan darah, profil darah, serta fungsi hati dan fungsi ginjal. Hasil pemeriksaan IMT pada kelompok I menunjukkan penurunan bermakna dibandingkan dengan baseline, dari $24,71 \mathrm{~kg} / \mathrm{m}^{2}$ menjadi 23,99 $\mathrm{kg} / \mathrm{m}^{2}$. Pada kelompok II terjadi peningkatan IMT rata-rata yang bermakna dibandingkan dengan baseline, dari $25,03 \mathrm{~kg} / \mathrm{m}^{2}$ menjadi $25,71 \mathrm{~kg} / \mathrm{m}^{2}$.

Uji keamanan dilakukan dengan melihat hasil pemeriksaan profil darah, tekanan darah, serta fungsi hati dan ginjal. Subjek yang mendapat terapi kombinasi ekstrak bulus bawang putihkunyit menunjukkan penurunan hemoglobin, leukosit, dan trombosit, tetapi penurunannya tidak bermakna, sedangkan hematokrit, PT, APTT, dan INR meningkat, tetapi tidak bermakna.

Subjek yang mendapat terapi glibenklamid menunjukkan penurunan kadar hemoglobin, hematokrit, leukosit, trombosit dan PT, tetapi penurunannya tidak bermakna, sedangkan APTT dan INR meningkat tidak bermakna dan masih dalam batas normal.

Kelompok I menunjukkan penurunan tekanan sistolik rata-rata, dari $134,37 \mathrm{mg} / \mathrm{dL}$ pada minggu ke-2 menjadi $126,25 \mathrm{mg} / \mathrm{dL}$ pada minggu ke14 , secara statistik tidak bermakna $(\mathrm{p}=0,16)$. Tekanan diastolik mengalami peningkatan ratarata yang tidak bermakna, dari 81,87 pada minggu ke-2 menjadi 83,75 pada minggu ke-14, dan nilai

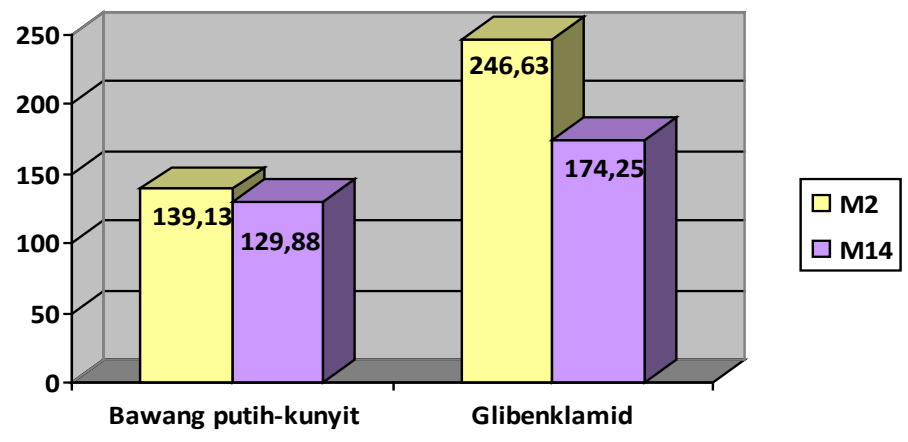

Gambar 2 Diagram Nilai Glukosa Darah 2 Jam PP Rata-rata pada Minggu ke-2 dan ke-14 


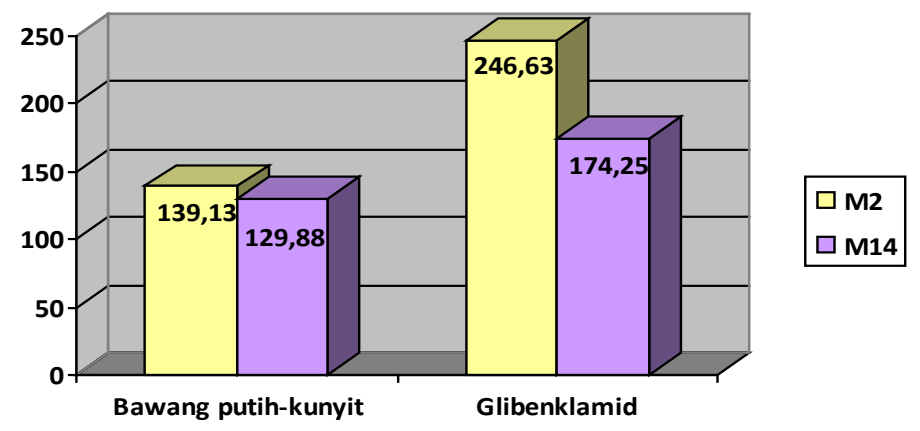

\section{Gambar 3 Diagram HbA1c Rata-rata Kadar pada Minggu ke-2 dan Minggu ke-14}

rata-rata masih dalam batas normal. Disimpulkan penggunaan kombinasi ekstrak bulbus bawang putih-kunyit tidak mempengaruhi tekanan darah.

Pada kelompok II tekanan sistolik dan diastolik mengalami penurunan dari $130 \mathrm{mg} /$ dL dan $82,5 \mathrm{mg} / \mathrm{dL}$ pada minggu ke-2 menjadi $124,37 \mathrm{mg} / \mathrm{dL}$ dan $79,37 \mathrm{mg} / \mathrm{dL}$ pada minggu ke14. Penurunan ini tidak bermakna secara statistik $(\mathrm{p}=0,148$ dan 0,180$)$. Disimpulkan kedua obat tidak mempengaruhi tekanan darah.

Hasil pemeriksaan fungsi hati (SGOT, SGPT) dan fungsi ginjal (ureum, kreatinin) pada saat skrining (minggu ke-2/setelah diet) semua subjek berada dalam batas normal. Hasil pemeriksaan ureum dan kreatinin pada minggu ke-14 atau akhir terapi pada kelompok I menunjukkan nilai rata-rata dalam batas normal. Subjek yang diberi terapi kombinasi ekstrak bawang putih-kunyit menunjukkan penurunan tidak bermakna kadar SGOT $(5,36 \pm 8,02)$, dan SGPT $(5,18 \pm 6,89)$. Hal ini terjadi karena efek lain dari curcumin, yaitu sebagai hepatoprotektor sehingga fungsi hati tidak terganggu, ${ }^{7}$ sedangkan kelompok II menunjukkan peningkatan nilai SGOT $(-11,5 \pm$ $28,61)$ dan SGPT $(-25,33 \pm 69,53)$ rata-rata yang tidak bermakna.

Keluhan klasik seperti poluria, polidipsia dan polifagia dialami oleh hampir semua subjek. Keluhan klasik terjadi pada 16/16 subjek, mengalami parestesi pada tangan dan kaki 16/16 subjek, penurunan berat badan yang tiba-tiba 1/16 subjek, pandangan buram 3/8 subjek, dan pusing 2/16 subjek.

Subjek yang mendapatkan terapi kombinasi bawang putih-kunyit mengalami perbaikan, yaitu keluhan klasik, pandangan buram, dan parestesi

Tabel 2 Keluhan Pederita

\begin{tabular}{|c|c|c|c|c|c|c|c|c|}
\hline \multirow[b]{2}{*}{ Jenis Keluhan } & \multicolumn{4}{|c|}{ Kombinasi Ekstrak } & \multicolumn{4}{|c|}{ Glibenklamid } \\
\hline & Awal & $\mathbf{N}$ & Akhir & $\mathbf{N}$ & Awal & $\mathbf{N}$ & Akhir & $\mathbf{N}$ \\
\hline Poliuria & + & $8 / 8$ & - & 0 & + & $8 / 8$ & - & 0 \\
\hline Polidipsia & + & $8 / 8$ & - & 0 & + & $8 / 8$ & - & 0 \\
\hline Polifagia & + & $8 / 8$ & - & 0 & + & $8 / 8$ & - & 0 \\
\hline Parestesia & + & $8 / 8$ & - & 0 & + & $8 / 8$ & \pm & $2 / 8$ \\
\hline Penurunan BB & + & $1 / 8$ & \pm & $1 / 8$ & - & 0 & - & 0 \\
\hline Penglihatan buram & + & $2 / 8$ & - & 0 & + & $1 / 8$ & + & $1 / 8$ \\
\hline Pusing & - & 0 & - & 0 & + & $2 / 8$ & + & $1 / 8$ \\
\hline Mual & - & 0 & - & 0 & - & 0 & + & $1 / 8$ \\
\hline Muntah & - & 0 & - & 0 & - & 0 & + & $1 / 8$ \\
\hline Kram pada kaki & - & 0 & - & 0 & - & 0 & + & $1 / 8$ \\
\hline Badan dingin & - & 0 & - & 0 & - & 0 & + & $1 / 8$ \\
\hline
\end{tabular}


tangan dan kaki berkurang. Selama penggunaan obat, subjek tidak mengalami keluhan selain sendawa berbau bawang putih. Rasa mual, muntah, dan pusing tidak terjadi selama terapi 3 bulan terhadap delapan subjek yang mendapat terapi kombinasi bawang putih dan kunyit.

Subjek yang diterapi glibenklamid mengalami perbaikan keluhan klasik, tetapi parestesi tidak berkurang serta $2 / 16$ subjek mengalami rasa dingin di seluruh tubuh dan sampai penelitian selesai rasa dingin tidak berkurang, satu subjek mengalami pusing, satu subjek mengalami muntah-muntah, satu subjek mengalami kram pada kaki di akhir terapi, dan satu orang merasakan kaku pada tangan sebelah kiri sampai akhir terapi.

Penderita yang tidak melanjutkan terapi dikatakan sebagai subjek dengan intent to treat. Pengamatan subjek ITT adalah subjek yang diterapi sesuai protokol dan subjek yang tidak sesuai protokol serta subjek lost of control. Pada kelompok ini terdapat tiga penderita yang mengalami lost of control, yaitu dua orang pada kelompok obat uji dan satu orang pada kelompok glibenklamid. Hasil terapi pada kelompok ini tidak dapat dianalisis karena subjek yang terdapat pada kelompok ini tidak mencukupi.

\section{Pembahasan}

Penggunaan kombinasi ekstrak bulbus bawang putih dan rimpang kunyit pada penelitian ini dapat menurunkan kadar glukosa darah puasa, hal ini menunjukkan perbaikan kemampuan sel $\beta$ dalam mensekresikan insulin sehingga insulin dapat digunakan untuk melepaskan glukosa dari hati ke dalam sel dan kemudian disimpan dalam bentuk glikogen dan dikeluarkan menjadi energi. ${ }^{1}$ Penurunan kadar glukosa darah puasa juga menunjukkan penurunan produksi glukosa di hati. ${ }^{12,13}$ Penelitian ini menunjukkan penggunaan kombinasi ekstrak bulbus bawang putih dan rimpang kunyit memiliki efek yang berbeda dengan glibenklamid.

Pemeriksaan glukosa darah 2 jam setelah makan, menunjukkan ambilan glukosa di jaringan perifer dan keadaan ini bergantung pada sensitivitas insulin terhadap jaringan ini. Jumlah asupan karbohidrat sangat mempengaruhi pemeriksaan ini karena asupan karbohidrat dapat meningkatkan konsentrasi glukosa plasma dan menstimulasi pelepasan insulin dari sel B. Penurunan kadar glukosa darah 2 jam setelah makan menunjukkan adanya perbaikan profil glukosa darah di jaringan perifer dan peningkatan sensitivitas insulin terhadap jaringan ini.

HbA1c merupakan penilaian kadar hemoglobin yang terglikosilasi dalam eritrosit, serta menunjukan konsentrasi glukosa dalam darah. Penurunan kadar HbA1c menunjukkan perbaikan pengendalian glukosa dalam darah oleh kedua obat dan hasil terapi selama 3 bulan menunjukkan perbaikan profil glukosa.

Penurunan kadar insulin yang terjadi pada kelompok I menunjukkan bahwa sensitivitas insulin meningkat, sekresi insulin belum dapat diperbaiki, tetapi terjadi peningkatan toleransi glukosa. Pada kelompok II kadar insulin meningkat, hal ini menunjukkan peningkatan sekresi insulin.

Mekanisme kerja ekstrak kunyit sebagai antidiabetes menunjukkan efek yang bermanfaat dari curcumin setelah diberikan pada hati tikus yang mengalami diabetes melitus. Enzim yang pentinguntukmengubahglukosamenjadiglikogen menjadi lebih tinggi pada tikus yang diterapi curcumin dibandingkan dengan tikus kontrol. Enzim ini diduga menghambat peningkatan glukosa setelah makan. ${ }^{14}$ Efek antiinflamasi dan antioksidan dari kunyit juga dapat menurunkan resistensi insulin dan mencegah terjadinya respons inflamasi pada tikus yang mengalami diabetes melitus tipe 2 yang disebabkan obesitas. Ditemukan juga bahwa penggunaan curcumin dapat meningkatkan adinopektin karena dapat memperbaiki sensitivitas insulin pada tikus yang resisten terhadap insulin. ${ }^{15}$ Curcumin juga dapat menekan produksi glukosa di hati dengan mengaktivasi AMP kinase dan menghambat glucose-6-phosphatase dan phosphoenolpyruvate carboxykinase. ${ }^{15}$

Efek antidiabetes dari bawang putih menunjukkan bahwa ekstrak bawang putih dapat menjaga kadar glukosa dalam kadar normal. Ekstrak bawang putih dinyatakan lebih efektif dibandingkan dengan glibenklamid. Efek hipoglikemik ini ditunjukkan dengan adanya komponen aktif dari bawang putih, yaitu allicin. Mekanisme kerja bawang putih masih belum jelas, bawang putih dapat berpotensi terhadap insulin di dalam plasma, yaitu dengan meningkatkan sekresi insulin dari sel beta pankreas. ${ }^{16}$

Kunyit dan bawang putih, keduanya dapat berkontribusi dalam memperbaiki kadar HbAlc pada penderita diabetes melitus. ${ }^{17}$ Peningkatan kadar HbA1c dapat meningkatkan faktor komplikasi pada penderita diabetes melitus juga berkontribusi pada peningkatan risiko penyakit hati. ${ }^{18}$ Peningkatan 1\% HbA1c sebanding dengan peningkatan $12 \%$ penyakit hati. ${ }^{19}$ Penelitian secara in vitro menunjukkan bahwa curcumin dapat menghambat terjadinya glikosilasi dari hemoglobin dalam konsentrasi glukosa yang tinggi. ${ }^{16}$ Efek hipoglikemik dan antioksidan kunyit dan bawang putih berhubungan dengan penurunan kadar glukosa darah dan hemoglobin 
terglikasi. ${ }^{20}$ Kunyit dan bawang putih merupakan kombinasi yang potensial untuk menurunkan kadar glukosa darah dan kadar HbAlc serta dapat menurunkan faktor risiko penyakit jantung.

Parameter penunjang seperti indeks massa tubuh (IMT) dihitung untuk mengetahui ada tidaknya obesitas pada penderita. Obesitas dihubungkan dengan adanya penurunan toleransi glukosa, perubahan hemostatis insulin, penurunan metabolik insulin, dan penurunan stimulasi insulin terhadap glukosa. Keadaan obesitas dapat menimbulkan resistensi insulin, dengan kata lain peningkatan berat badan juga IMT maka terjadi pula peningkatan resistensi insulin. ${ }^{12}$ Penurunan IMT diduga terjadi karena adanya peningkatan kadar insulin dan perbaikan kontrol glukosa. ${ }^{1}$

Hasil penelitian ini menunjukkan bahwa penggunaan ekstrak bulbus bawang putih dan rimpang kunyit dengan dosis 2,4 g/hari dapat mempercayai efek antidiabetes, tetapi tidak sebaik glibenklamid. Kombinasi ini dapat digunakan sebagai salah satu bahan pilihan untuk terapi diabetes melitus tipe 2, akan tetapi perlu dilakukan penelitian lebih lanjut dengan subjek yang lebih banyak dan untuk mengetahui mekanisme kerja kedua ekstrak tersebut.

\section{Daftar Pustaka}

1. Powers AC. Diabetes mellitus at endocrinology and metabolism. Dalam: Gibson RJ, penyunting. Harisson's principles of internal medicine. Edisi ke-16. New York. McGrawHill; 2005. hlm. 2152-71.

2. PERKENI. Konsensus pengelolaan dan pencegahan diabetes melitus tipe 2 di Indonesia. PERKENI. 2006

3. WHO. Definition and diagnosis of diabetes mellitus and intermediate hyperglycemia. Report of a WHO/IDF Consultation. 2006.

4. WHO Monograph on selected medical plants. Vol 1. Geneva: WHO; 1999.

5. Thomson M, Al-Amin ZM, Al-Qattan KK, Shaban LH, Ali M. Antidiabetic and hypolipidaemic properties of garlic (Allium sativum) in streptozotocin-induced diabetic rats. Int J Diabetes Metab. 2007;15:108-15.

6. Swanston-Flatt SK. Traditional plant treatments for diabetes. Studies in normal and streptozotocin diabetic mice. Diabetologia. 1990;33:462-4.

7. Ishita C, Kaushik B. Turmeric and curcumin: biological actions and medical applications (Review). Current Science. 2004;87:44-50.

8. Kuroda M, Mimaki Y, Nishiyama T, Mae T, Kishida H, Tsukagawa M, dkk. Hypoglicemic effects of turmeric (curcuma longa L. rhizomes) on genetically diabetic KK-Ay mice. Biol Pharm Bull. 2005;28(5):937-9.

9. Deviana R. Pengaruh pemberian ekstrak bulbus bawang putih (allium sativum) dan rimpang kunyit (curcuma domestica) serta kombinasinya terhadap profil lipoprotein dan glukosa darah tikus (Tesis). Bandung: Institut Teknologi Bandung; 2005.

10. Dewi M. Pengaruh kombinasi ekstrak bulbus bawang putih (allium sativum) dan rimpang kunyit (curcuma domestica) terhadap penurunan kadar glukosa darah dan perbaikan profil lipoprotein pada penderita diabetes tipe 2 disertai dislipidemia (Tesis). Bandung: Institut Teknologi Bandung; 2007.

11. Subiakto Y. Pengaruh pemberian kombinasi ekstrak bulbus bawang putih (allium sativum) dan rimpang kunyit (curcuma domestica) terhadap fungi hati dan ginjal, serta histologi organ tikus (Tesis). Bandung: Institut Teknologi Bandung; 2005.

12. Curtis L, Charles AR. Diabetes mellitus. Endocrinologic disorders. Pharmacotheray a pathophysiologic approach. Edisi ke-6. New York: McGraw-Hill; 2006.

13. Tirosh A, Shai I, Manova D.T, Israeli E, Pereg D, Shochat T, dkk. Normal fasting plasma glucose level and type 2 diabetes in young man. N Engl J Med. 2005;353:145462.

14. Weisberg SP, Leibel R, Tortoriello DV Dietary curcumin significantly improves obesity-associated inflammation and diabetes in mouse models of diabesity. Endocrinology. 2008;149:3549-58.

15. Fujiwara H, Hosokawa M, Zhou X, Fujimoto S, Fukuda K, Toyoda K, dkk. Curcumin inhibits glucose production in isolated mice hepatocytes. Diabetes Res Clin Pract. 2008;80:185-90.

16. Jain SK, Rains J, Jones K. Effect of curcumin on protein glycosylation, lipid peroxidation, and oxygen radical generation in human red blood cells exposed to high glucose levels. Free Radic Biol Med. 2006;41:92-6.

17. Saudek CD, Herman WH, Sacks DB, Bergenstal RM, Edelman D, Davidson MB. A new look at screening and diagnosing diabetes mellitus. J Clin Endocrinol Metab. 2008;93:2447-53.

18. Selvin E, Coresh J, Golden SH, Brancati FL, Folsom AR, Steffes MW. Glycemic control and coronary heart disease risk in persons with and without diabetes. Arch Int Med. 2005;165:1910-6.

19. Iribarren C, Karter AJ, Go AS, Ferrara A, Liu JY, Sidney S, Selby JV. Glycemic control and heart failure among adult patients with diabetes. Circulation. 2001;103:2668-73. 
Ame: Efek Antidiabetes Kombinasi Ekstrak Bawang Putih (Allium sativum Linn.) dan Rimpang Kunyit (Curcumma domestica Val.)

20. Eun MJ, Myung SC, Un JJ, Myung JK, Hye JK, Seon MJ, dkk. Beneficial effects of curcumin on hyperlipidemia and insulin resistance in high-fat-fed hamster. Metab Clin Exp. 2008;57:1576-83. 